TITLE:

\title{
CONTRIBUTIONS TO JAPANESE ASCIDIAN FAUNA -X.NOTES ON SOME ASCIDIANS COLLECTED IN OSAKA BAY(2)-
}

$\operatorname{AUTHOR}(\mathrm{S})$ :

Tokioka, Takasi

CITATION:

Tokioka, Takasi. CONTRIBUTIONS TO JAPANESE ASCIDIAN FAUNA -X.NOTES ON SOME ASCIDIANS COLLECTED IN OSAKA BAY(2)-. PUBLICATIONS OF THE SETO MARINE BIOLOGICAL LABORATORY 1954, 4(1): 75-98

\section{ISSUE DATE:}

1954-11-20

URL:

http://hdl.handle.net/2433/174498

RIGHT: 
CONTRIBUTIONS TO JAPANESE ASCIDIAN FAUNA

X. NOTES ON SOME ASCIDIANS COLLECTED IN OSAKA BAY $(2)^{1)}$

\author{
TAKASI TOKIOKA
}

Seto Marine Biological Laboratory, Sirahama

With Plates V-VIII and 7 Text-figures

After the publication of my previous report (1951) on some ascidians of Osaka Bay, I have had chances to examine three ascidian materials, all collected by Mr. R. IsiBASI in the south-eastern part of Osaka Bay. Thus, the ascidian fauna of the Bay increased much in number as shown below :

1. Amaroucium multiplicatum

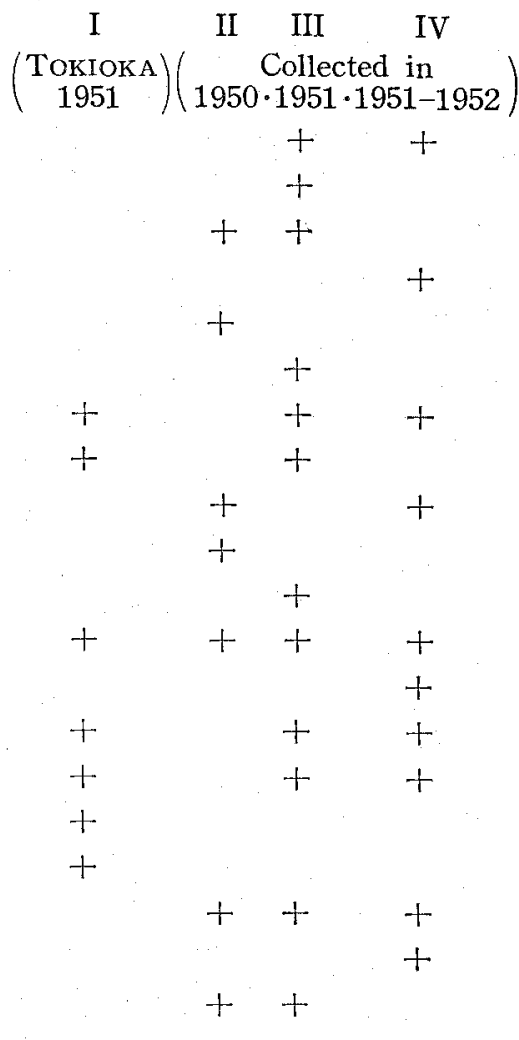

1) Contributions from the Seto Marine Biological Laboratory, No. 241.

Publ. Seto Mar. Biol. Lab., IV (1), 1954. (Article 9) 
21. Styela partita

22. Styela plicata

22a. Styela plicata f. tenuis

23. Styela isibasii

24. Styela clava

25. Pyura michaelseni

26. Pyura lepidoderma

27. Pyura mirabilis

28. Boltenia isibasii n. sp.

29. Halocynthia roretzi

30. Eugyrioides glutinans

Number of species

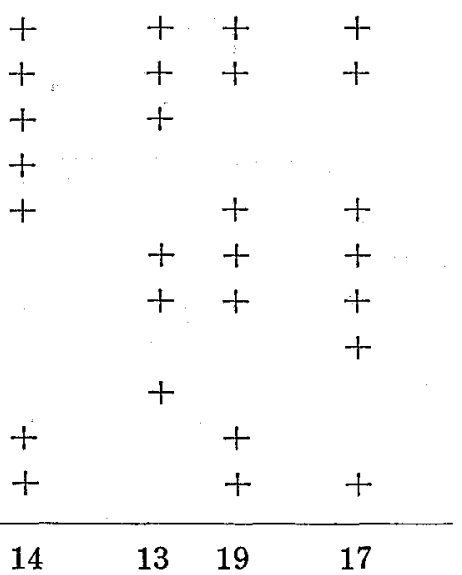

14

$\begin{array}{lll}13 & 19 & 17\end{array}$

Four new species and a new form are described here, besides some notes on other species already known. Before going further I with to express my hearty thanks to Mr. R. IsIBASI for his kindness in offering me these precious materials.

\section{Amaroucium multiplicatum (SLUITER), 1909}

(P1. V, Fig. 1)

Aplidium multiplicatum-SLUITER 1909.

Amaroucium multiplicatum-TOKIOKA 1953.

Two colonies encrusting the stem of Sargassum, respectively $28 \mathrm{~mm} \times 9 \mathrm{~mm}$ and $15 \mathrm{~mm} \times 12 \mathrm{~mm}$ in extent and both $3-4 \mathrm{~mm}$ in thickness. Zooids orange in colour, $2.5 \mathrm{~mm}-3 \mathrm{~mm}$ in length in large ones, and form at some places irregular groups surrounding each a small round common cloacal aperture. Abdomen about two thirds of thorax, postabdomen as long as the rest of the body. Atrial languet of moderate size and ending simply. Eight to ten longitudinal muscles on each side of the thorax. Seven-eight rows of stigmata, each containing about a dozen stigmata. Anus bilobed and situated on the level of the 5th transverse vessel. About 15 plications on stomach. The proximal end of the rectum does not form distinct coeca as in SLuiter's description. Testicular follicles up to 20 in number in examined zooids.

Remarks: Some differences found between these colonies and those found in Sagami Bay can not be considered to be of specific significance. Collected from the coast of Kozima on June 20, 1951. There is a small colony encrusting Styela plicata found in the fourth material. This specimen was in rather poor state of preservation and I could only confirm the existence of 7-8 rows of stigmata on some zooids. Am. californicum RitTer \& Forsyth 1917 from the Californian Coast and especially Am. accarense MillaR 1953 from the Gold Coast resemble very closely the present species. 


\section{Amaroucium pliciferum REDIKORZEV, 1927}

(Pl. V, Figs. 2-5)

Amaroucium pliciferum-REDIKORZEV 1927; Tokioka 1953.

Amaroucium roseum-ОкА, А. 1927.

One colony from Satomati-ura of Okinosima on May 6, 1951 . It is $47 \mathrm{~mm}$ $\times 18 \mathrm{~mm}$ in extent and $15 \mathrm{~mm}$ in thickness. Test soft gelatinous; zooids reddish, darker on the thorax, especially around the apertures. They are ca. $10 \mathrm{~mm}$ in length; postabdomen as long as the rest of the body. Thorax with about 16 longitudinal muscles on each side. Rows of stigmata 13 on the left and 14 on the right, each comprising 12-16 stigmata. Anus situated on the level of the 10th transverse vessel. The outline of ciliated groove differs slightly from that described previously (TokiokA 1953) and forms a longitudinal slit, ca. $40 \mu$ in length. About 20 plications on stomach, distinct coeca at the proximal end of the rectum. Up to 6 eggs and embryos in the incubatory chamber, all coloured orange-red.

\section{Didemnum (Didemnum) moseleyi (HeRdman), 1886}

(Fig. 1)

Leptoclinum moseleyi-HERDMAN 1886.

Didemnum moseleyi-Sluiter 1909, 1914 ; Van NAme 1918; Tokioka 1949, 1953, 1954.

Leptoclinum album--ОкА, А. 1927.

Three small colonies encrusting St. areolata from Minami-hama of Nagasaki on May 20, 1951 (A, D, G): They are respectively $7 \mathrm{~mm} \times 5 \mathrm{~mm}, 4 \mathrm{~mm} \times 3 \mathrm{~mm}$ and $8 \mathrm{~mm}$ $\times 2.5 \mathrm{~mm}$ in extent and all $1.5 \mathrm{~mm}$ in thickness. The colony grayish brown in colour and sprinkled with minute white spicules. They are distributed in the surface layer evenly, but not densely; the dark brownish inner matrix can be seen through the test. The lower layer below the middle stratum contains spicules very sparsely. Large spicules $37 \mu$ in diameter, with $7-8$ rays on the equatorial plane. Average distance between zooids ca. $330 \mu$. Thorax ca. $550 \mu$ and abdomen ca. $500 \mu$ in length. Thoracic tubercle indistinct. Testicular follicle 1.

A large colony found in the second material (B, C, E, F, H, I): It is encrusting the basal portion of Ecklonia sp., somewhat irregular in shape and as a whole pale grayish purple in colour; $80 \mathrm{~mm} \times 80 \mathrm{~mm}$ in extent in wide parts and 1-2 $\mathrm{mm}$ in thickness. Test translucent, pale yellowish brown in colour; whitish zooids and dark substratum are seen through. Zooids are arranged in irregular groups, each comprising 10-20 zooids; average distance between zooids in a group ca. $320 \mu$. Spicules are distributed sparsely along the upper and lower walls of thoracic lacunae, but quite absent in thin superficial and thick bottom layers. Average diameter of common spicules $38 \mu$, the maximum diameter $51 \mu$. Granulated cells, up to $29 \mu$ in 


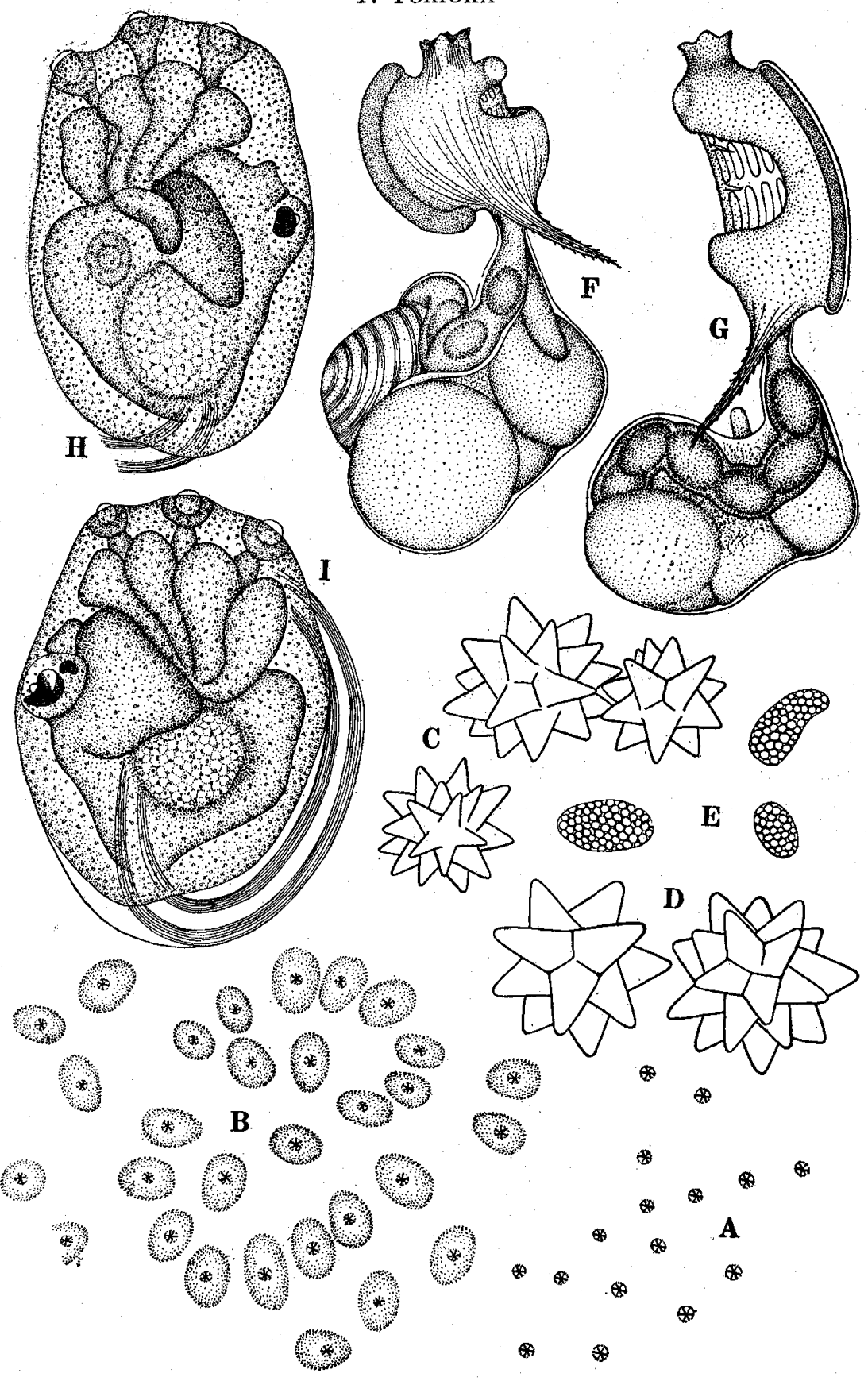

Fig. 1. Didemnum (Didemnum) moseleyi (HERDMAN).

A, D, G-small colonies from Minami-hama of Nagasaki. A-A part of the colony surface, $\times 25$. D-Spicules, $\times 630$. G-Zooid from right side, $\times 75$.

$\mathrm{B}, \mathrm{C}, \mathrm{E}, \mathrm{F}, \mathrm{H}, \mathrm{I}$-large colony in the second material. B-A group of zooids, $\times 25$. C-Spicules, $\times 440$. E-Granulate cells, $\times 440$. F-Zooid from left side, $\times 75$. $H-$ Larva from left side, $\times 110$. I-Larva from right side, $\times 110$. 
length, are distributed throughout the layer containing spicules. Thorax $320 \mu$ long in contracted state and whitish in colour, abdomen ca. $500 \mu$ in length and yellowish orange in colour. Thoracic tubercle indistinct. About 6 stigmata in each row. Testicular follicle 1, proximal part of vas deferens coils 7-8 times. Trunk of larva $550 \mu$ in length on the average. Three attachment processes arranged linearly, ampullae 4 pairs; larval test granulated.

Remarks: These colonies may be safely identified as Did. (Did.) moseleyi in states showing somewhat peculiar distribution of spicules.

\section{Didemnum sp.}

(P1. VI, Fig. 9)

Colonies encrusting Styela plicata. They are $18 \mathrm{~mm} \times 33 \mathrm{~mm} \sim 27 \mathrm{~mm} \times 35 \mathrm{~mm}$ in extent in wide parts and less than $1 \mathrm{~mm}$ in thickness. Test transparent and slightly milky white in colour. The surface generally smooth, although some elevations and depressions occur irregularly. Common cloacal aperture quite obscure on the present material. Spicules absent.

Average distance between zooids $520 \mu$. Thorax ca. $450 \mu$ long in contracted state, abdomen ca. $610 \mu$ in length. The anterior half of the thorax is pigmented in dark brownish colour, consequently branchial apertures are discernible distinctly as darkly coloured small circles. The alimentary canal is arranged as in common species of the genus Didemnum (Didemnum). Gonad immature.

The absence of the spicules and the existence of pigmentation in the anterior half of the thorax are the characteristics of the present specimens. However, it is hardly possible to identify the specimen decidedly at present, because thorases are all contracted strongly, abdomens are in rather worse condition of preservation and gonads are quite immature.

\section{Leptoclinides nigrothorax $\mathrm{n}$. sp.}

$$
\text { (P1. V, Figs. 6-8) }
$$

A small $9 \mathrm{~mm} \times 8 \mathrm{~mm}$ colony in the second material. It is $2 \mathrm{~mm}$ in thickness and has a layer of faecal pellets along the attachment surface. Test transparent; spicules are distributed very sparsely merely along the upper wall of the thoracic lacunae; a superficial spiculeless layer is discernible. Spicules usually ca. $45 \mu$ in diameter and very like those of Did. (Did.) moseleyi. There are many elongate granulated cells in the test, which may be $45 \mu$ long in larger ones. Average distance between zooids ca. $420 \mu$.

Zooid: Thorax and abdomen respectively ca. $500 \mu$ in length. Thoracic mantle dark purplish black in colour. A short atrial siphon protrudes out at the postero- 
dorsal corner of the thorax. Thoracic tubercle at the postero-ventral part of the thorax on each side, elliptical in shape and usually containing a dozen granules. Retractile muscle very small. About 6 stigmata in each of 4 rows; dorsal languets slender; tentacles ca. 12 . Stomach and mid-intestine unpigmented, only the rectum is faintly pigmented. Gonad immature; several testicular follicles?

Remarks: The small size of zooids and the dark pigmentation of the thorax are the characteristics of the present new species. The former characteristic recalls to our mind the resemblance with Polysyncraton nigropunctatum SLUITER.

D. B. Carlisle and A.I. Carlisle (1954) abandoned the genus Leptoclinides and placed some species of the abandoned genus under Polysyncraton. I wish, however, to notice on the fact that there are distinct differences between species of Leptoclinides and those of Polysyncraton occurring in the north-western Pacific. Besides the existence of the atrial siphon in Leptoclinides, the existence of the atrial languet in Polysyncraton and the situation of the ovary on the testis in the same subgenus are considered to be noteworthy. Thus I prefer to retain the opinion of separating Leptoclinides from Polysyncraton till further crucial studies are completed.

\section{Leptoclinides echinatus n. sp.}

(Fig. 2)

A $45 \mathrm{~mm} \times 30 \mathrm{~mm}$ colony encrusting the barnacles caught in the net at the northern side of Okinosima on June 10, 1951. It is 1-2 mm in thickness and encloses a Musculus sp. in a part of the test which is rather tough, pale grayish yellow-brown in colour, with irregular pale reddish orange pattern and sprinkled with many white dots representing zooids. There are many finger-shaped or slender triangular protuberances on the surface. Spicules distributed evenly but very sparsely throughout the test, except for the superficial layer which is quite devoid of spicules. They are $40 \mu$ in diameter in larger ones and have each up to 10 rays on the equatorial plane. The appearance of rays resembles closely that of Did. (Did.) moseleyi. Reddishorange colouration of the test is due to the pigmentation found just below the superficial spiculeless layer.

Zooid: Average distance between zooids $590 \mu$. Thorax $860 \mu$ and abdomen $910 \mu$ in length in an examined zooid. A small roundish thoracic tubercle is found near each postero-lateral side of the basal portion of the short atrial siphon projecting out from the postero-dorsal corner of the thorax and contains granules within it. Testis very large, occupying the whole lateral side of the abdomen. Testicular follicles number from 4 to 12 , most frequently ca. 10. The proximal end of vas deferens

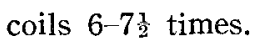



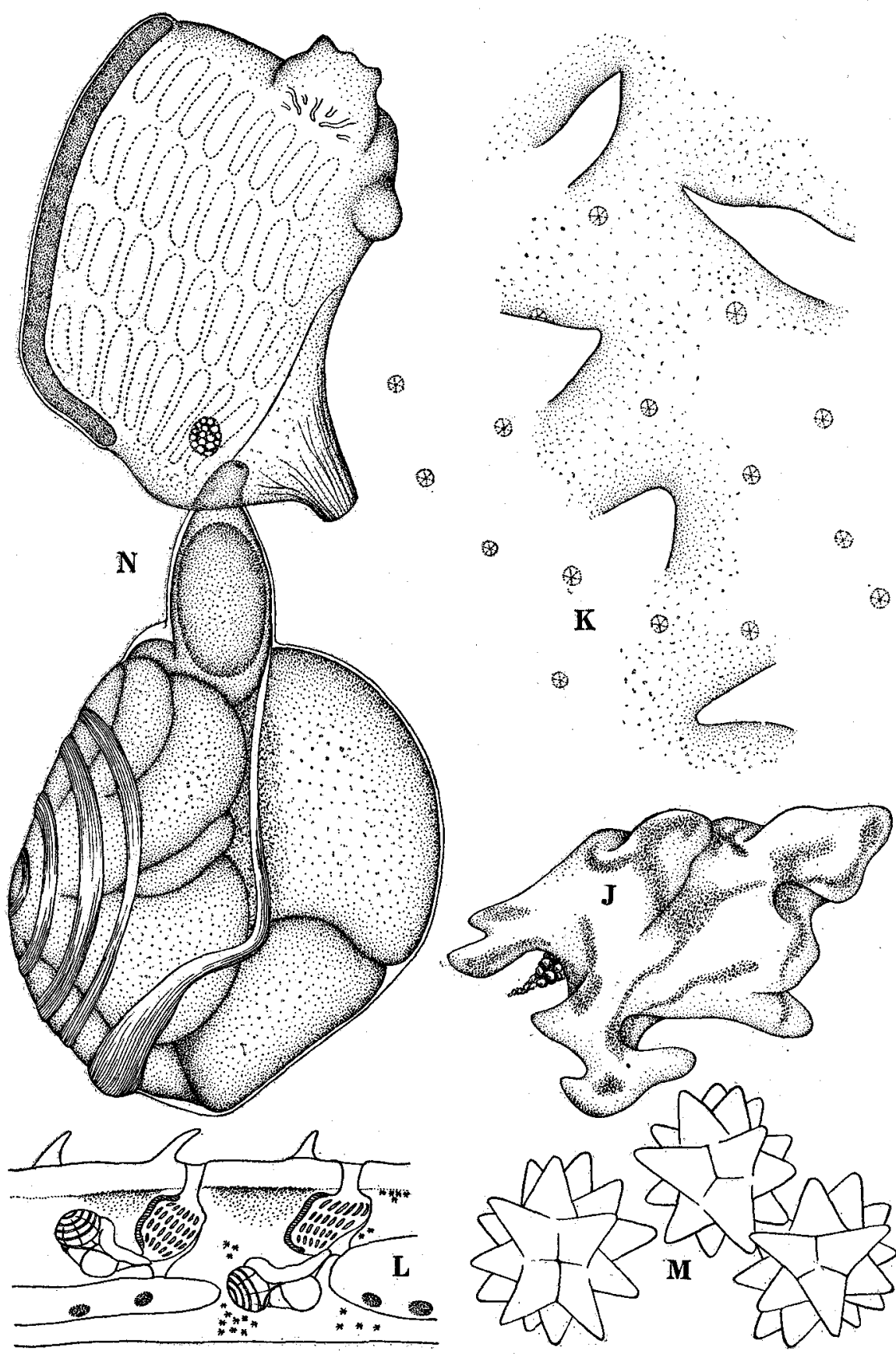

Fig. 2. Leptoclinides echinatus n. sp.

$\mathrm{J}-45 \mathrm{~mm} \times 30 \mathrm{~mm}$ colony. K-A part of the colony surface, $\times 25$. L-Optical section of colony, enlarged. $M-$ Spicules, $\times 630, \quad N-$ Zooid from left side, $\times 75$. 
Remarks: The echinate appearance of the test surface and the large testis comprising much more follicles than in Lept. ocellatus (SLUITER) and Lept. madara TokIOKA, both provided with large zooids, can be accepted as characteristics of the present new species.

\section{Distaplia dubia (OKA), 1927}

Leptobotrylloides dubium-ОкA. A. 1927.

Distaplia japonica-ToKIoKa 1951.

Distaplia dubia-TокıокA 1953.

Colonies from Minami-hama of Nagasaki on May 20, 1951: Test dark grayish blue in colour and sprinkled with whitish zooids. Stomach yellowish in colour; testicular follicles up to 15 in number. Trunk of larva ca. $1.1 \mathrm{~mm}$ in length.

Colonies from Tannowa on June 10, 1952: Encrusting Sargassum. Longitudinal plications of the stomach rather obvious.

\section{Ciona intestinalis (Linnaeus), 1767}

(Pl. VI, Fig. 10)

Ciona intestinalis-HARTMEYer 1906 ; OKA, A. 1927, 1935 ; TOKIOKA 1951, 1953.

Some individuals were attached to the oyster shells collected in Osaka Bay on April 5, 1951. Some of the supporting processes of the inner longitudinal vessels are of "pulchella"-type.

\section{Ascidia alpha ТокіокA, 1953}

Ascidia alpha-TokiokA, T. (1953 a) : Contributions to Japanese Ascidian Fauna V. Ascidians collected near the Marine Biological Laboratory of Hirosima University in the Inland Sea (1), Publ. Seto Mar. Biol. Lab., III (1), pp. 10-11, Fig. 6.

Two individuals in the second material: Bodies respectively $25 \mathrm{~mm}$ and $26 \mathrm{~mm}$ in length. Branchial aperture 8 and atrial aperture 6-7 lobed.

An individual in the 4th material: The body $28 \mathrm{~mm}$ in length and attached to the substratum by the whole left side. Test soft cartilaginous, considerably thick on the right side and pale grayish yellow in colour. The surface seems to be smooth originally and free from foreign matters, although some irregular grooves may occur on the surface in preservation. Mantle body $17 \mathrm{~mm}$ in length including the branchial siphon and flesh in colour. Both siphons relatively long; atrial siphon situated on the level of the anterior fourth of the body length excluding the siphon. The anterior margin of the intestinal loop does not reach the base of the atrial siphon, consequently anus opens slightly in front of the anterior end of the loop. 
The axis of the second intestinal loop passes the pyloric end of the stomach which is elongate and with ca. 5 plications on the left side. Oesophagus opens to the branchial sac at the middle of the range from the base of the atrial siphon to the posterior end of the body. Inner longitudinal vessels ca. 40 and transverse vessels ca. 80 on each side. Gonad immature.

\section{Ascidia gamma n. sp.}

(Pl. VI, Figs. 12-15)

A $21 \mathrm{~mm}$ long individual in the second material. The body roughly oval in outline and attached to the substratum by the whole left side. Branchial aperture subterminal, atrial aperture situated near the branchial; both apertures sessile. Test soft cartilaginous and translucent. The surface is roughly smooth, although several irregular grooves are observable.

Mantle body: Branchial siphon terminal, atrial siphon situated slightly in front of the middle of the body; both siphons of moderate length and coloured yellowish near the aperture. Branchial aperture 8- and the atrial 7-lobed.

Branchial sac: Plications scarcely discernible. Thirty-two inner longitudinal and ca. 70 transverse vessels on each side. Three to four stigmata in a mesh. Tentacles ca. 50, ciliated groove $\mathrm{C}$-shaped and opened anteriorly, and dorsal lamina with many ribs protruding beyond the margin of the lamina into small yellowish orange prominences. Supporting papillae of the inner longitudinal vessels are rather small.

Alimentary system: Intestinal loop strongly inclined dorsads, the anterior margin of the loop reaches the middle of the range between the bases of both siphons. The axis of the second intestinal loop passes the pyloric end of the stomach which is elongate and longitudinally plicated faintly. Gonad immature.

Remarks: It is not impossible that the present specimen represents merely a deformed individual of the preceding species or As. ahodori OkA. It is, therefore, desirable that the present name is accepted as a provisional one.

\section{Ascidia zara OKA, 1935}

(Pl. VI, Fig. 16)

Ascidia zara- ОкА, А. 1935 ; Токіока 1953, 1953 a.

Two individuals in the third material. They were found on the oyster shells collected on April 5, 1951 and both $25 \mathrm{~mm}$ in length. Test transparent. The anterior margin of the intestinal loop reaches beyond the base of the atrial siphon up to nearly $2 / 3$ of the range between the bases of both siphons. Anus situated near 
the middle of the visceral mass. Stomach with ca. 8 plications on each side. Ciliated groove U-shaped. Ovary purplish black in colour in an examined specimen.

\title{
12. Ascidia sydneiensis divisa (SLUITER), 1898
}

(Pl. VI, Fig. 17)

\author{
? Ascidia pyriformis-HERdMAN 1882. \\ Ascidia canaliculata-SLUITER 1885. \\ Ascidia divisa-SlutTer 1898, 1904; HARTMEYer 1906; TOKIOKA 1951. \\ Ascidia sydneiensis (in part)-HARTMEYER 1919; VAN NAME 1945. \\ Ascidia sydneiensis divisa-ToKюKA 1953.
}

Six individuals ( $21 \mathrm{~mm}-55 \mathrm{~mm}$ in length) in the second, a $17 \mathrm{~mm}$ long individual in the third (from the oyster shell collected off Ozaki on Feb. 18, 1951) and 6 individuals $(24 \mathrm{~mm}-65 \mathrm{~mm}$ in length) in the fourth material. In all individuals the ciliated groove describes a very complex configuration. Exceptionally in the $65 \mathrm{~mm}$ long individual, the anterior margin of the intestinal loop ends at the anterior base of the atrial siphon. (1) The existence of many protuberances on the test and the correspondent mantle prominences. (2) The rectum is slightly thickened at the bottom part of the second intestinal loop. These two features may be added to the characteristics of the present species. In the $17 \mathrm{~mm}$ long individual, the body is somewhat purplish near the apertures.

\section{Botryllis primigenus ОкА, 1928}

Botryllus primigenus-OKA, A. 1928; VAN NAME 1945; TOKIOKA 1951, 1953.

A small colony referable to this species with some doubts was collected at Tannowa on June 10,1952 . It must be noticed that there are found some colonies representing some intermediate states of system-forming between the present species and next one.

\section{Botryllus communis OKA, 1927}

Botryllus communis-OKA, A. 1927, 1927 a ; ToKIOKA 1951, 1951 a, 1953, 1953 a ; CHIN 1934 (Lingnan Sci. Journ. Canton, Vol. 13, No. 3, p. 490).

A purplish black botryoid colony from the oyster shell collected on Feb. 18, 1951. It consists of small spherical masses, ca. $6 \mathrm{~mm}$ in diameter. Besides, small colonies on Zostera collected st Tannowa on June 10, 1952.

\section{Botrylloides violaceum OKA, 1927}

Botrylloides violaceum-OKA, A. 1927 a ; TокıоKA 1949, 1951, 1951a, 1953, 1953a, 1954.

? Botrylloides carnosum-OKA, A. 1927 a.

Botrylloides aurantium-OKA, A. 1927. 
A damaged reddish brown colony encrusting a specimen of Styela plicata found in the fourth material. In the third material there are a considerable number of purplish-brown and flesh colonies collected at Minami-hama of Nagasaki on May 20, 1951 and a flesh colony collected at Satomati-ura of Okinosima near Tomogasima on May 6, 1951. Zooids in the former specimens are provided each with about ten orange $\sim$ orange brown pigment flecks along each side of the endostyle.

\section{Symplegma reptans (OKA), 1927}

\section{Polyzoa pacifica Токіока, 1951}

Both species were not included in the second-fourth materials.

\section{Cnemidocarpa areolata (HELLER), 1878}

(Fig. 3)

Styela areolata-Herdman 1906, VAN NAME 1918, TOKIOKA 1950.

Tethyum areolata-HARTMEYER 1909.

Cnemidocarpa areolata-TokiokA 1953, 1953a, 1954.

Cnemidocarpa valborg-HARTMEYER 1919.

Five individuals (11-22 $\mathrm{mm}$ in length) in the second materials, a $12 \mathrm{~mm}$ long individual (collected on April 5, 1951) and 3 individuals $(15 \mathrm{~mm}-38 \mathrm{~mm}$ in length, from Minami-hama of Nagasaki on May 20, 1951) in the third material and 2 individuals (11 and $14 \mathrm{~mm}$ long individuals attached to each other side by side) in the fourth material: Mantle yellowish orange $\sim$ pale grayish purple or brown in colour. Both siphons and dorsal side are coloured reddish-brown or dark greenish. Small individuals in the fourth material are devoid of endocarps on the inner surface of the mantle excepting those in the first intestinal loop.

Branchial sac: Inner longitudinal vessels arranged as follows :

$11 \mathrm{~mm}$ long individual :

$$
\begin{array}{lllllllll}
\text { Left } & \text { D. } & 5(10) & 4(12) & 4(11) & 4(8) & 3 \mathrm{~V} . \\
\text { Right } & \text { D. } & 4(9) & 4(11) & 4(11) & 4(12) & 4 \mathrm{~V} .
\end{array}
$$

$14 \mathrm{~mm}$ long individual :

$\begin{array}{lllllll}\text { Left } & \text { D. } & 4(12) & 3(10) & 4(10) & 4(8) & 3 \mathrm{~V} . \\ \text { Right } & \text { D. } & 3(10) & 4(12) & 4(12) & 3(11) & 4 \mathrm{~V} .\end{array}$

$38 \mathrm{~mm}$ long individual :

$$
\begin{array}{llllll}
\text { Left } & \text { D. } 10(12) & 4(12) & 4(15) & 4(10) & 4 \mathrm{~V} . \\
\text { Right } & \text { D. } 6(13) & 4(16) & 4(16) & 4(12) & 4 \mathrm{~V} .
\end{array}
$$

The $11 \mathrm{~mm}$ long individual has ca. 20 tentacles excluding minute ones (30-40 including minute ones). Ciliated groove deep U-shaped in all examined specimens. In 
the $14 \mathrm{~mm}$ long individual thick transverse and parastigmatic vessels alternate regularly.

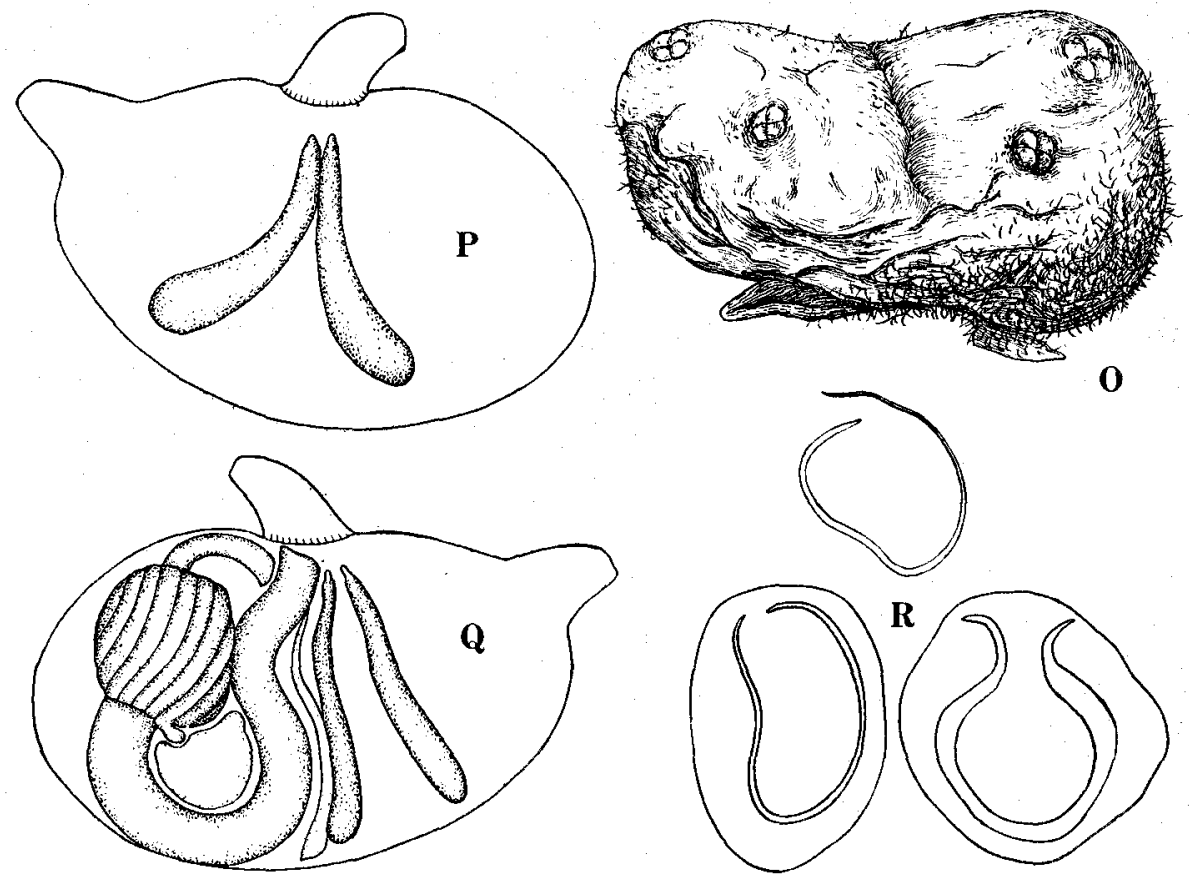

Fig. 3. Cnemidocarpa areolata (HELLER).

$\mathrm{O}-14 \mathrm{~mm}$ and $11 \mathrm{~mm}$ long individuals attached each other side by side. $\mathrm{P}-$ Right half of mantle body ( $14 \mathrm{~mm}$ long ind.), from inside. Q-Left half of mantle body (14 $\mathrm{mm}$ long ind.), from inside. $\mathrm{R}$-Ciliated grooves, enlarged.

Alimentary system: Number of endocarps in the first intestinal loop is $3(22 \mathrm{~mm}$ long individual) -5 ( $38 \mathrm{~mm}$ long individual) in examined specimens. The $14 \mathrm{~mm}$ long individual has merely a large endocarp in the loop besides a thin and long one along the anterior margin of the intestinal loop. Margin of anus plain ( $38 \mathrm{~mm}$ long individual) or slightly undulating. Plications on stomach ca. 20 in the $14 \mathrm{~mm}$ long individual. Minute but distinct pyloric coecum in the $14 \mathrm{~mm}$ long individual.

Gonad: 11, $14 \mathrm{~mm}$ long individuals :

$$
\text { Left } 2 \text { Right } 2
$$

$22 \mathrm{~mm}$ long individual :

Left 2 Right 3

$38 \mathrm{~mm}$ long individual :

$$
\text { Left } 1 \text { Right } 2
$$




\section{Cnemidocarpa fertilis forma minor nov.}

(Fig. 4 ; Pl. VII, Fig. 18)

A small ovoid individual attached by the ventral side to the surface of a Pyura michaelseni found in the fourth material. It is $10 \mathrm{~mm}$ long, $7.5 \mathrm{~mm}$ wide and $5.5 \mathrm{~mm}$ in height. Branchial aperture subterminal, atrial aperture near the middle of the dorsal side; both apertures 4-lobed and sessile. Test leathery, tough, somewhat reddish in colour on the dorsal side and very thin on the ventral side. The surface is irregularly wrinkled and holds some sand grains and other foreign matters along the periphery. Mantle pale flesh in colour. Small endocarps are scattered sparsely on the inner surface of the mantle. Atrial tentacles extremely delicate but long, ca. 40 in number.

Branchial sac: Inner longitudinal vessels are arranged as follows:

$$
\begin{array}{llllllll}
\text { Left } & \text { D. } & 0(12) & 2(8) & 1(10) & 2(6) & 1 \text { V. } \\
\text { Right } & \text { D. } & 0(12) & 1(10) & 1(11) & 1(5) & \text { ? V. }
\end{array}
$$
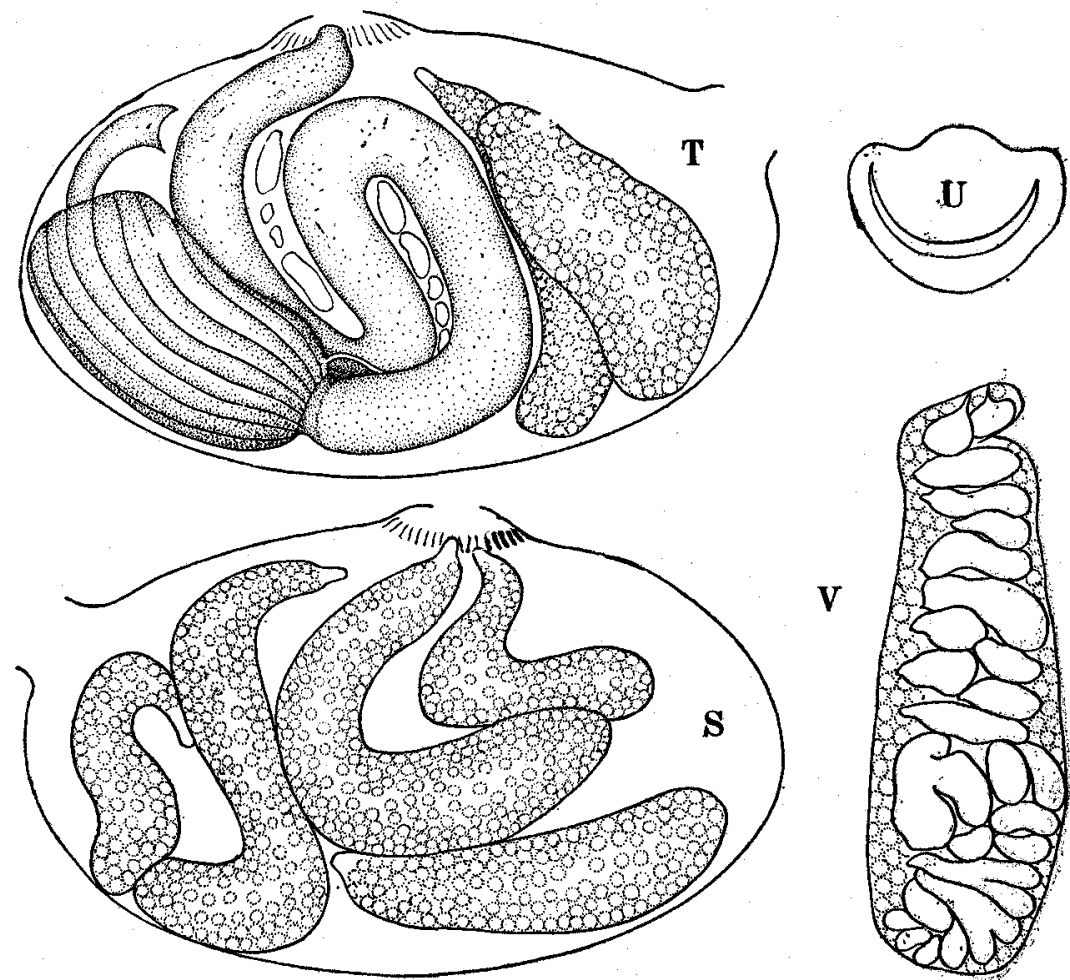

Fig. 4. Cnemidocarpa fertilis f. minor nov.

S-Right half of mantle body, inside. T-Left half of mantle body, inside. U - Ciliated groove, enlarged. V-Attachment surface of a $4 \mathrm{~mm}$ long gonad. 
Thick and thin transverse vessels alternate regularly, parastigmatic vessels present. Four to six stigmata in a mesh. Tentacles ca. 30 including large and small ones, but excluding minute ones; they are yellowish white in colour. Ciliated groove crescent-shaped.

Alimentary system: Anterior end of the first intestinal loop beyond the middle of the body, 2 large and 4 small endocarps in the loop. The second intestinal loop is very deep and contains 2 large and 2 small endocarps; the axis passes through behind the pyloric end of the stomach which is elongate, less than a half of the ventral branch of the first intestinal loop and with ca. 12 plications on each side. Pyloric coecum absent.

Gonad: Two on the left and 5 on the right side. Large ones reach as long as $10 \mathrm{~mm}$. Testicular follicles situated roughly transversely on the attachment surface.

Remarks: The present specimen is safely considered as a minor form of $C n$. fertilis, which attained to the maturity at such a small size. The characteristic arrangement of the alimentary canal seems to guarantee the present idea.

\section{Cnemidocarpa macrogastra (ОКA), 1935}

Styela macrogastra-ОкА. А. 1935.

Cnemidocarpa macrogastra-ТокІокA 1953, 1953a, 1953b.

A $20 \mathrm{~mm}$ long grayish white individual in the second material. The third material contains 7 individuals, namely 3 individuals (up to $9 \mathrm{~mm}$ in length, found on the oyster shell collected on April 5, 1951), 2 individuals (up to $18 \mathrm{~mm}$ long, from Minami-hama of Nagasaki on May 20, 1951) and 2 individuals $(20-27 \mathrm{~mm}$ in length, found on the oyster shell collected on March 9, 1951). The $18 \mathrm{~mm}$ long individual attached to the substratum by the right posterior side of the body; test is slightly reddish around the apertures and the mantle is orange yellow in colour fading towards the ventral side. The $20 \mathrm{~mm}$ long individual in the third material is attached to the substratum by the left side of the body. The neighbourhood of apertures somewhat greenish. The $27 \mathrm{~mm}$ long individual is very peculiar in the appearance. Test is grayish, wrinkled very irregularly on the surface; the posterior half of the body is covered with a thin muddy coat. Mantle yellowish in colour, reddish orange around the apertures. Stomach much longer than at least a half of the ventral branch of the first intestinal loop.

\section{Styela partita (Stimpson), 1852}

(Pl. VII, Figs. 19-20)

Cynthia partita-STIMPson 1852.

Styela variabilis-ALDER \& HANCOCK 1907. 
Styela partita var. bermudensis-VAN NAME 1902.

Styela partita bermudensis-VAN NAME 1921.

Tethyum partitum-VAN NAME 1912, SALFI 1931.

Styela partita-VAN NAME 1921, 1924, 1945 (Bull. American Mus. Nat. Hist., Vol. 84, pp. 290293, Pl. 3 figs. 7-8, Pl. 10 fig. 3, Figs. 179 E, 180 C, 188); HARANT 1930 ; BERrill 1932; OKA, A. 1934 ; Pérès 1949, 1951; Tokioka 1951, 1953, 1953a, 1954 ; Millar 1953 (Proc. Zool. Soc. London, Vol. 123, Pt. II, pp. 311-312).

Common in the bay. Twenty-three individuals $(4 \mathrm{~mm}-18 \mathrm{~mm}$ in length) in the second material, 3 individuals, up to $7 \mathrm{~mm}$ in length and being attached to the specimen of Styela plicata found in the fourth material, and 14 individals in the third material. The sources of the last specimens are:

No. 1 Two $17 \mathrm{~mm}$ long individuals from Satomati-ura of Okinosima near Tomogasima on May 6, 1951.

No. 2 A $15 \mathrm{~mm}$ long individual from the oyster shell caught off Ozaki on Febr. 18, 1951.

No. 3 Five individuals (up to $26 \mathrm{~mm}$ in length) from the oyster shells collected on April $5,1951$.

No. 4 A $12 \mathrm{~mm}$ long individual from Minami-hama of Nagasaki on May 20, 1951.

No. 5 Three individuals (14-18 $\mathrm{mm}$ in length).

No. 6 A $22 \mathrm{~mm}$ long individual attached to the barnacle caught in a net at the northern side of Okinosima on June 10, 1951.

No. 7 A $12 \mathrm{~mm}$ long somewhat elongate individual from the estuary of the river Onosato on April 24, 1951.

The preserved specimens are usually yellowish white grayish yellow with reddish brown tint around the apertures. The $15 \mathrm{~mm}$ long individual (No. 2) is oval in outline and quite smoothly surfaced. It has 2 immature gonads on each side; the inner longitudinal vessels arranged on the left side as D. 4 (15) 4 (14) 4 (14) 5 (9) 3V. The $26 \mathrm{~mm}$ long individual (in No. 3) has 2 gonads on the right, but one on the left, missing the anterior one. The $22 \mathrm{~mm}$ long individual (No, 6) has 3 gonads on the right side.

\section{Styela plicata (LESUEUR), 1823}

(Pl. VII, Fig. 21)

Styela plicata-TRAustedt 1885; TraUstedT \& WELTNER 1894; HeRDMAN 1899 ; HARTMEYER 1905, 1906; REDIKORZEV 1916; VAN NAME 1921, 1945; OKA, A. 1927, 1935; HaRANT 1930; PÉRẼs 1949, 1951; TOKIOKA 1951a, 1953; KOTT 1952.

Tethyum plicatum-VAN NAME 1912, 1931.

Nineteen individuals $(8 \mathrm{~mm}-40 \mathrm{~mm}$ in length) in the second material, 4 individuals (up to $17 \mathrm{~mm}$, from the oyster shells collected on April 5, 1951) in the third and 5 individuals $(30 \mathrm{~mm}-50 \mathrm{~mm}$ in length) in the fourth material. The specimens in the third material resemble superficially St. partita. They are oval in outline, attached to the substratum by the posterior end; test cartilaginous, milky white as a whole and coloured reddish brown solely around the 4-lobed apertures. The sur- 
face is nearly smooth, except a few faint wrinkles. Mantle pale flesh in colour. In all individuals of this material the gonad was not yet formed. The number of gonads in specimens in the fourth material is as follows:

$\begin{array}{llrll}30 \mathrm{~mm} \text { long individual } & \text { Left } & 2 & \text { Right } & 7 \\ 35 \mathrm{~mm} & 3 & 7 \\ 35 \mathrm{~mm} & " & 2 & 7 \\ 35 \mathrm{~mm} & " & 3 & 7 \\ 50 \mathrm{~mm} & & 3 & 8\end{array}$

It is a noteworthy fact that there are a considerable number of individuals which have 3 gonads on the left side.

22a. Styela plicata f. tenuis Токıока, 1951

Styela plicata f. tenuis TоKIOKA 1951a.

Five individuals (20-39 $\mathrm{mm}$ in length) in the second material. I have observed a few individuals of this form collected near the estuary of Edogawa in the inner part of Tokyo Bay.

23. Styela isibasii Токтока, 1951

Not represented in the second $\sim$ fourth materials.

24. Styela clava HERDMAN, 1881

Styela clava Herdman 1881, 1882; Drasche 1884; Traustedt 1885; Hartmeyer 1906; OKA, A. 1927, 1935; TокіокA 1951, 1951a, 1953, $1953 \mathrm{a}$.

Botryorchis clava REDIKORZEV 1916.

Three individuals (a $12 \mathrm{~mm}$ long individual and two individuals, both $22 \mathrm{~mm}$ in body length and with $18 \mathrm{~mm}$ long stalk, attached to the oyster shells from Ozaki on Febr. 18, 1951) in the third material and a $21 \mathrm{~mm}$ long individual in the fourth material.

\section{Pyura michaelseni (ОKA), 1906}

(Pl. VII, Figs. 22-25)

Halocynthia michaelseni-OKA, A. (1906): Notizen über japanische Ascidien I, Annot. Zool. Japon., Vol. VI, Part 1, pp. 46-47.

Cynthia michaelseni-OKA, A. 1927, 1935.

Pyura michaelseni-TokıоKa 1949.

Nine individuals ( $22 \mathrm{~mm}-63 \mathrm{~mm}$ in length) in the second material, 31 individuals (less than $14 \mathrm{~mm}$ in length, being crowed on the oyster shells collected at Ozaki on Febr. 18 and April 5, 1951) in the third material and 10 individuals (7-45 mm in 
length) in the fourth material. The test is cartilaginous (exceptionally it may be leathery) and usually purplish or slightly reddish purple in colour, but fades to white in preservation. In small individuals, the test is somewhat translucent and pale reddish-purple $\sim$ milky white with a faint gray-purplish tint. The surfaces of smaller individuals are usually smooth, excepting a few small prominences; while the surface is completely wrinkled and carries many foreign matters in the ventral half in larger individuals, although wrinkles, grooves and adhering foreign matters decrease remarkably on the dorsal area. The animals are attached to the substratum by the ventral side and rarely two individuals are found being fused with each other side by side. The test may reach $3.5 \mathrm{~mm}$ in thickness in some thickened parts, but it is less than $1 \mathrm{~mm}$ at some thin places. Both apertures are sessile and marked each with 8 (4 in young individuals) lobules. The dorsal ridge uniting both apertures in $P$. sanderi is quite obscure in the present species. The mantle body is reddish or pale brownish purple in the dorsal side, but paler in the ventral side; siphons deep red, both apertures 4-lobed.

Branchial sac: The arrangement of the inner longitudinal vessels in smaller individuals is as follows:

$5 \mathrm{~mm}$ long roughly spherical individual:

$\begin{array}{llllllllll}\text { Left } & \text { D. } & 0(5) & 0(6) & 0(10) & 1(8) & 1(7) & 0(3) & 0 \mathrm{~V} . \\ \text { Right } & \text { D. } & 0(8) & 0(5) & 1(9) & 0(6) & 1(6) & 1 & (3) & 0 \mathrm{~V} .\end{array}$

$11 \mathrm{~mm}$ long individual :
Left
D.
$1(11)$
1 (13)
1 (11) 1 (11) 1 (6) $0 \mathrm{~V}$
Right
D. 0 (13) 1 (11) 1 (12)
1 (13) 1 (11) 1 (10) $2 \mathrm{~V}$.

In the former, about 3 stigmata are counted in a mesh, parastigmatic vessels present, and ciliated groove simply $\mathrm{U}$-shaped.

Alimentary system: Liver is divided into a few masses which are not aggregated compactly and yellowish brown in colour.

Gonad: Immature gonad is observed already in a $11 \mathrm{~mm}$ long individual. In a $36 \mathrm{~mm}$ long individual, the left gonad consists of 14 and the right one of 15 genital capsules.

Remarks: This ascidian is most frequently pierced with the bivalve, Musculus sp., a small shell of which was ever found in a $5 \mathrm{~mm}$ long individual.

\section{Pyura lepidoderma ToKIOKA, 1949}

(Fig. 5)

Tokioka, T. (1949): Contributions to the Japanese Ascidian Fauna I. Ascidians collected by Prof. MiYadi and Mr. Masur during the bottom survey 1939-40, Publ. Seto Mar. Biol. Lab., Vol. I, No. 1, p. 10, Pl. 5 figs. 1-3. 
TоKiоKa 1953a, 1953b.

Five individuals ( $8 \mathrm{~mm}-15 \mathrm{~mm}$ in length) in the second material, 2 individuals (both $15 \mathrm{~mm}$ in length, being attached to the shell fragment from Ozaki on Dec. 18, 1951) in the fourth material and 5 individuals (12 mm-19 mm in length) in the third material. Most of the specimens in these materials are somewhat erect oval in outline and attached to the substratum by the posterior end of the body. Test usually whitish in colour. The mantle body is yellowish orange reddish orange in colour when alive, especially coloured deeply on the dorsal side and on the siphons.

Branchial sac: Inner longitudinal vessels arranged as follows:

$12 \mathrm{~mm}$ long individual (on the oyster shell from Ozaki on Febr. 18, 1951):
Left
D. 1 (12) 1
(9) 1 (14) 2
(12) 1
(8) 2 (6) $3 \mathrm{~V}$.
Right
D. 1
2 (6) 2
(12) 2
(12) 2
(9) 2
(4) $3 \mathrm{~V}$.

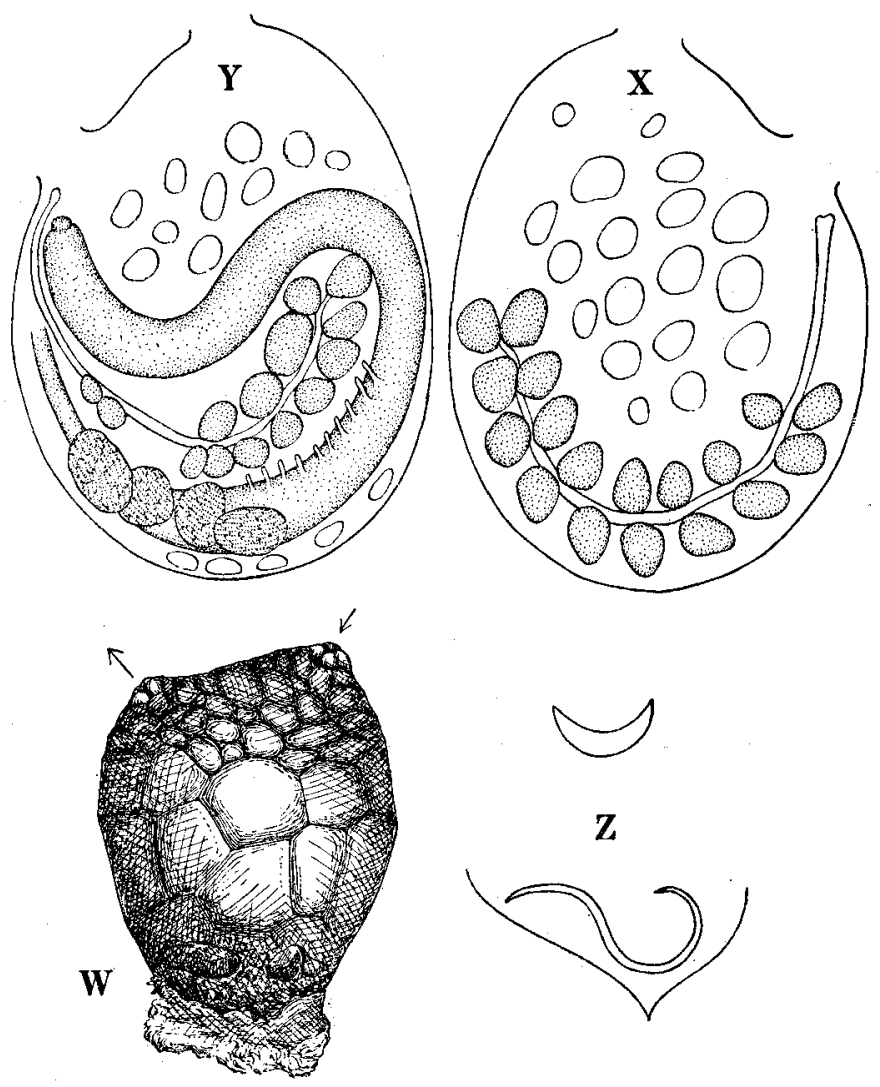

Fig. 5. Pyura lepidoderma Tokioka.

$\mathrm{W}-12 \mathrm{~mm}$ long oval individual. $\mathrm{X}-$ Right half of mantle body (12 $\mathrm{mm}$ long ind.), inside. $Y$-Left half of mantle body (12 $\mathrm{mm}$ long ind.), inside. Z-Ciliated grooves, enlarged. 
$19 \mathrm{~mm}$ long individual (from Minami-ura of Nagasaki on May 20, 1951):

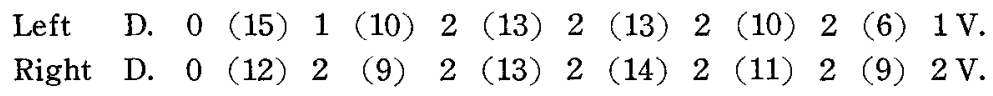

Three-five stigmata in a mesh in the $12 \mathrm{~mm}$ long individual, while 5-9 ones in the $19 \mathrm{~mm}$ long individual. Tentacles ca. 30 in the $19 \mathrm{~mm}$ long individual, including ca. 15 large tentacles and small ones of about the same number.

Alimentary system: Liver yellowish brown in colour and usually divided into anterior and posterior groups being combined with each other by a narrow piece of the same organ.

Remarks: A $12 \mathrm{~mm}$ long individual was found being quite deformed by the penetration of two shells of Musculus sp.

\section{Pyura mirabilis (V. DRASCHE), 1884}

(Pl. VII, Fig. 26 ; Pl. VIII, Figs. 27-33)

Cynthia mirabilis - v. Drasche, R.F. (1884): Ueber einige neue und weniger gekannte aussereuropäische einfache Ascidien, Denkschriften der mathem.-naturw. Cl., Bd. XLVIII, pp. 377-378, P1. VI Figs. 2-7.

Halocynthia mirabilis-OKA, A. 1906.

Cynthia mirabilis-OKa. A. 1927.

Pyura mirabilis-VAN NAME 1945.

Two individuals in the fourth material. They were collected on Dec. 18, 1951 and respectively $27 \mathrm{~mm}$ and $40 \mathrm{~mm}$ in length. The animal attached to the substratum by the underside; the branchial terminal of the oblong body is narrower than the atrial terminal. Test cartilaginous leathery, about $1 \mathrm{~mm}$ in thickness, and yellowish white in colour; only the branchial aperture is coloured orange. The surface of the perfectly preserved specimen is nearly smooth excepting a few faint transverse wrinkles and quite free from foreign matters.

Mantle body: About 25 conspicuous transverse muscles are arranged regularly on the dorsal side and ca. 10 thinner longitudinal muscles running beneath the former. The anterior half of the ventral side is occupied by ca. 10 thin longitudinal muscles, thin transverse muscles are confined along the periphery and lying beneath the longitudinal ones. Endocarps absent. Spinules on the distal part of the stomodaeum are ca. $65 \mu$ in length, tips are bluntly pointed.

Branchial sac: Seven folds on each side. Inner longitudinal vessels are arranged as follows in the $40 \mathrm{~mm}$ long individual:

$$
\begin{array}{lllllllllllll}
\text { Left } & \text { D. } & 2(13) & 3(10) & 2(9) & 3(11) & 3(12) & 3(11) & 1 & (8) & 0 \mathrm{~V} . \\
\text { Right } & \text { D. } & 2(14) & 2(9) & 3(8) & 3(11) & 3(12) & 3(12) & 2(7) & 0 \mathrm{~V} . \\
& \multicolumn{9}{c}{} & -93-
\end{array}
$$


The arrangement of the transverse vessels is somewhat irregular, usually ca. 5 medium thinner vessels between each pair of thicker ones. Parastigmatic vessels present. Five to eight stigmata in a mesh. Tentacle ca. 20, including large and small ones; the larger ones are 13-15 in number; branches in 2 orders. Ciliated groove $\mathrm{C}$-shaped opened anteriorly and with one or both arms incurled. Dorsal languets slender and long.

Alimentary system: Alimentary canal describes a simple and narrow U-shaped loop opened towards the atrial aperture. Gastric portion occupies a considerably wide range of the ventral branch of the intestinal loop. The anterior margin of the loop reaches the middle of the body in fully expanded specimens and to $2 / 3-3 / 4$ of the body length or more in contracted specimens. Liver forms a compact mass and greenish brown in colour. Margin of the anus undulating, but not divided into lobules.

Gonad: One on each side. Ovary is an elongate sac, slightly undulating on the right side and yellowish-brown in colour. Testicular follicles are arranged along each side of the gonad and pinkish in colour; they are complexly lobated.

Remarks: The appearance of the gonad resembles closely that of Herdmania momus. These saccular gonads differ distinctly from those found in many common species of the genus and consisting of a number of genital capsules. Is it an unreasonable idea to treat the species having saccular gonads, Herdmania momus, Pyura mirabilis and some species of Pyura, under a group separate from most of the species of Pyura having gonads consisting of genital capsules?

\section{Boltenia isibasii n. sp.}

(Fig. 6)

One specimen in the second material. The body is oblong, $30 \mathrm{~mm}$ long $\times 17 \mathrm{~mm}$ wide and $20 \mathrm{~mm}$ in height, being attached to the substratum by the ventral side. Both apertures situated subterminally at each end; siphons extremely short. Test leathery, very hard and reddish-orange in colour. The dorsal side is provided with many tubercular prominences, of which larger ones are aggregated in areas surrounding the apertures and smaller ones are distributed sparsely in other parts of the body. Many irregular grooves are found on the ventral side. Test ca. $1.8 \mathrm{~mm}$ in thickness and whitish on the innerside.

Mantle body: Mantle of moderate thickness and yellowish as a whole, being slightly coloured reddish orange near the apertures. Both transverse and longitudinal muscles are well developed, the latter lying beneath the former. Atrial velum very remarkable.

Branchial sac: Seven folds on each side. Inner longitudinal vessels arranged as follows: 


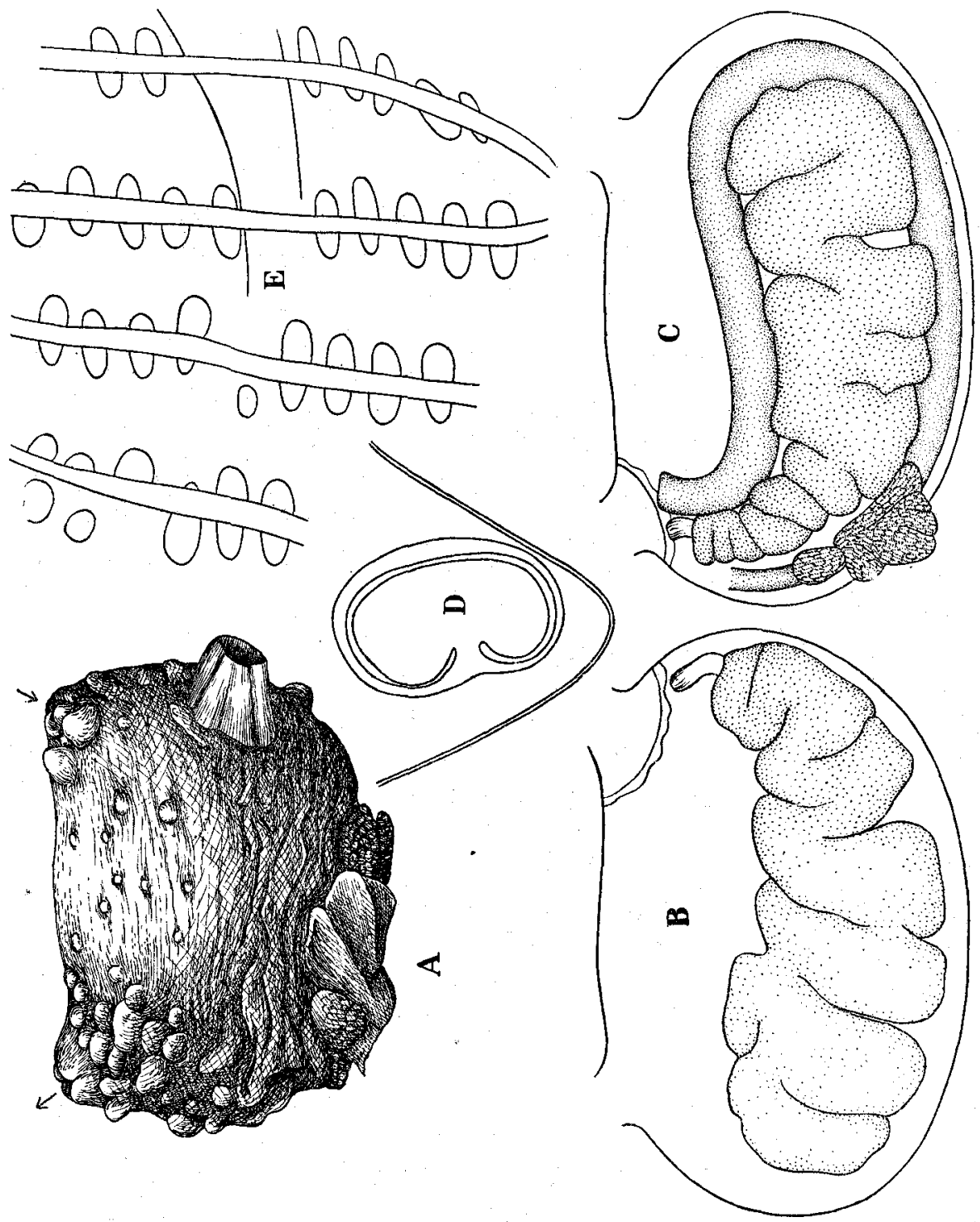

Fig. 6. Boltenia isibasii n. sp.

A- $-30 \mathrm{~mm}$ long individual, right side. B-Right half of mantle body, inside, C--Left half of mantle body, inside. D-Ciliated groove, enlarged. E-A part of branchal sac, inside, $\times 75$. 


$\begin{array}{lllllllllllllllll}\text { Left } & \text { D. } & 1 & (27) & 3 & (18) & 2 & (24) & 3 & (24) & 3 & (22) & 3 & (15) & 3 & (12) & 1 \mathrm{~V} . \\ \text { Right } & \text { D. } & 1 & (21) & 4 & (12) & 4 & (21) & 5 & (28) & 4 & (21) & 4 & (18) & 3 & (12) & 2 \mathrm{~V} .\end{array}$

A row of short stigmata under each longitudinal vessel. Nine large and the same number of small tentacles alternate regularly, besides a minute one at each interval; branches in 2 orders. Ciliated groove $\mathrm{C}$-shaped, opened to the left as we face it. Dorsal languets distinct.

Alimentary system: The alimentary canal forms a wide $\mathrm{U}$-shaped loop and with very shallow second intestinal loop. Gastric area small, liver whitish in colour and somewhat translucent. Anus plainly margined.

Gonad: Large one gonad on each side. It is lobated as shown in figures and yellowish in colour.

Remarks: The appearance of body which is wholly devoid of spines on the surface, resembles closely Halocynthia transversaria SuUtter (1904) from the Siboga Area. The latter differs, however, from the former in number of the branchial folds which are 6 ( 5 wide and 1 very narrow ones in $3 \mathrm{~cm}$ long individual) in the latter.

\section{Halocynthia roretzi (v. DRASCHE), 1884}

(cit. Text-fig. 20 in Ascidians of Sagami Bay)

Cynthia Roretzii-Drasche 1884, Traustedt 1885.

Halocynthia roretzi-HARTMEYER 1906; OKA, A. 1906 ; TOKIOKA 1951, 1953.

Cynthia roretzi f. typica + var. ivamiana + var. sikokiana-OKA, A. 1926.

Cynthia roretzi-ОкА, А. 1927, 1935.

Two individuals in the third material. They are respectively $28 \mathrm{~mm}$ and $27 \mathrm{~mm}$ in length, and attached to the oyster shells collected at Ozaki on Febr. 2, 1951. The body is nearly spherical, coloured orange in the anterior half and grayish in the posterior half and provided with many small spines around the apertures. Some of the spines have the thick basal portion. Thirteen folds on each side of the branchial sac, of which the 11th is confined in the posterior half of the sac, 12th in the posterior third and the 13th in the posterior fourth. Gonad not yet formed.

Remarks: Mr. R. ISIBASI told me that a considerable number of large individuals of the present species are fished by some inhabitants as food near Tannowa.

\section{Eugyrioides glutinans (MOELLER), 1842}

(Fig. 7)

Eugyra glutinans-TRAUSTEDT (in part) 1880, KIAER (in part) 1896, HARTMEVER (in part) 1903, VAN NAME 1945. 
Paramolgula arctica-BONNEvie 1896.

Paramolgula rara-KIAER 1896.

Eugyrioides schmidti-HARTMEYER 1911, 1912; RedikORzev 1916.

Eugyrioides glutinans-REDIKORZEV 1916 ; TOKIOKA 1953, 1953a.

Eugyrioides arctica-REDIKORzEv 1916.

Eugyrioides asamusi-OKA, A. 1930, 1935; TоKIоKA 1949.

Two $20 \mathrm{~mm}$ long individuals in the fourth material and 6 individuals $(13 \mathrm{~mm}$ $-30 \mathrm{~mm}$ in length) in the third material. Most of the present specimens are all very large. The $30 \mathrm{~mm}$ long individual dredged by a fishing boat off Ozaki on

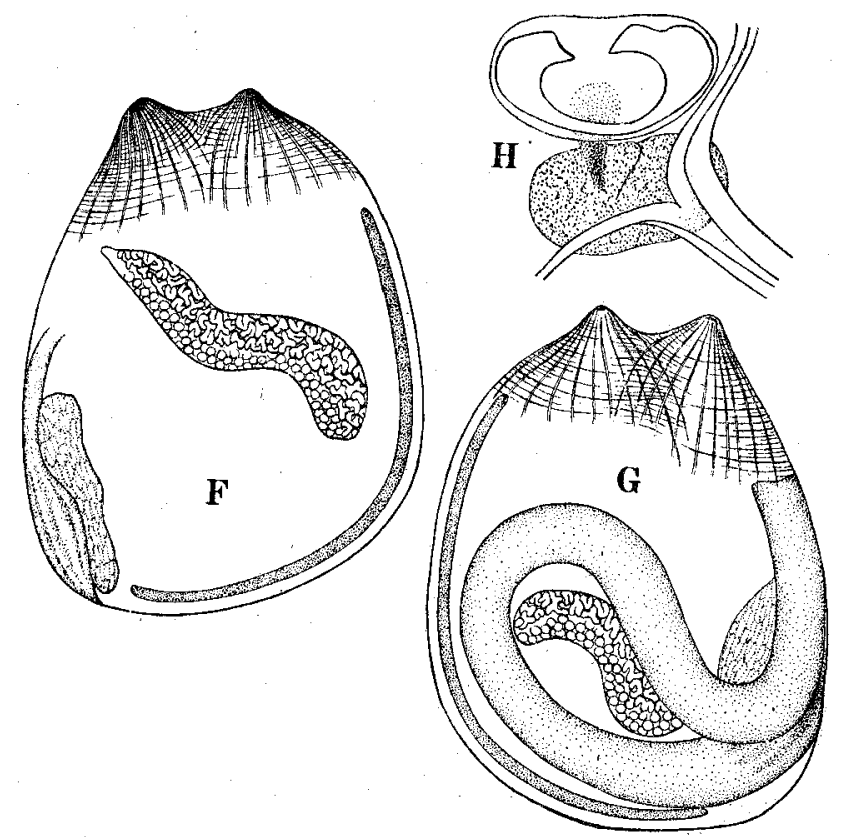

Fig. 7. Eugyrioides glutinans (MOELLER).

F-Mantle body from right side ( $18 \mathrm{~mm}$ long ind.). G--Mantle body from left side (18 mm long ind.). $\mathbf{H}$-Ciliated groove, subneural gland and anterior parts of wide and narrow dorsal laminae, enlarged.

Febr. 12, 1951 seems to be the maximum record in this species. The body is oval $\sim$ spherical in outline, covered wholly with mud except for the siphonal area which is pinkish in colour. About 20 short longitudinal muscles on the siphonal area of the body. The VIIl (ventral-most) longitudinal row of infundibula consists of $10(1.2 .2 .2 .2 .1)$ infundibula on the left and $11(1.2 .2 .2 .2 .2)$ ones on the right side in an examined $18 \mathrm{~mm}$ long specimen. Free margin of anus plain, testis pinkish in colour. 


\section{ADDENDUM : Pegea confoederata (FORSKÅL), 1775}

Two stranded aggregated forms are found in the fourth material. They are both $32 \mathrm{~mm}$ in length. There are a pair of short crests on the ventral side just in the position where the crest-like organs are situated in the aggregated form of $P$. $c$. bicaudata, although they are too faint to be detected easily.

\section{LITERATURE CITED}

(As to other literatures not listed below, cite TokiokA 1953.)

Carlisle, D. B. and CARlisle, A. I. (1954): Notes on the Didemnidae (Ascidiacea) I. The presence of Didemnum (Leptoclinides) faeröense (BJERKAN) in the Plymouth Area, J. Mar. biol. Ass. U. K., Vol. 33, pp. 21-25, Figs. 1-2.

Chin, T. G. (1934): A preliminary report on Amoy Tunicata, Lingnan Sci. Journ. Canton, Vol. 13 , No. 3 , pp. $487-491$, Pls. 53-54.

Kotт, P. (1952): The ascidians of Australia I. Stolidobranchiata LAHILle and Phlebobranchiata LAHILlE, Australian Journ. Mar. Freshwater Research, Vol. 3, No. 3, pp. 205-333, Text-figs. 1-183.

MillaR, R. H. (1953): On a collection of ascidians from the Gold Coast, Proc. Zool. Soc. London, Vol. 123, Pt. II. pp. 277-325, Text-figs. 1-26, Table 1.

TokiokA, T. (1953): Ascidians of Sagami Bay, Tokyo, pp. 315, Text-figs. 25, Pls. 79, 1 Map. (1953a): Contributions to Japanese ascidian fauna V. Ascidians collected near the Marine Biological Laboratory of Hirosima University in the Inland Sea (1), Publ. Seto Mar. Biol. Lab., III (1), pp. 1-25, Text-figs. 1-16. (1953b): Contributions to Japanese ascidian fauna VI. Simple ascidians of the Museum of Hukui, Ibid., pp. 27-32, Text-figs. 1-3, Pl. I.

(1954): Invertebrate fauna of the intertidal zone of the Tokara Islands VII. Ascidians, Ibid. III (3), pp. 239-264, Text-figs. 1-2, Pls. XVIII-XXXVII.

\section{EXPLANATION OF PLATE V}

Fig. 1. Amaroucium multiplicatum (SLUITER), zooid from right side, enlarged.

Figs. 2-5. Amaroucium pliciferum REDIKORZEv.

2-Zooid from right side, enlarged.

3-Atrial languet, magnified.

4-Ciliated groove, magnified.

5-Larva, not yet fully developed, $\times 75$.

Figs. 6-8. Leptoclinides nigrothorax n. sp.

6-Zooid from left side, $\times 75$.

$7-$ Spicules, $\times 440$.

$8-$ Granulate cells, $\times 440$. 
Publ. Seto Mar. Biol. Lab., IV, 1 (1954) PLATE V

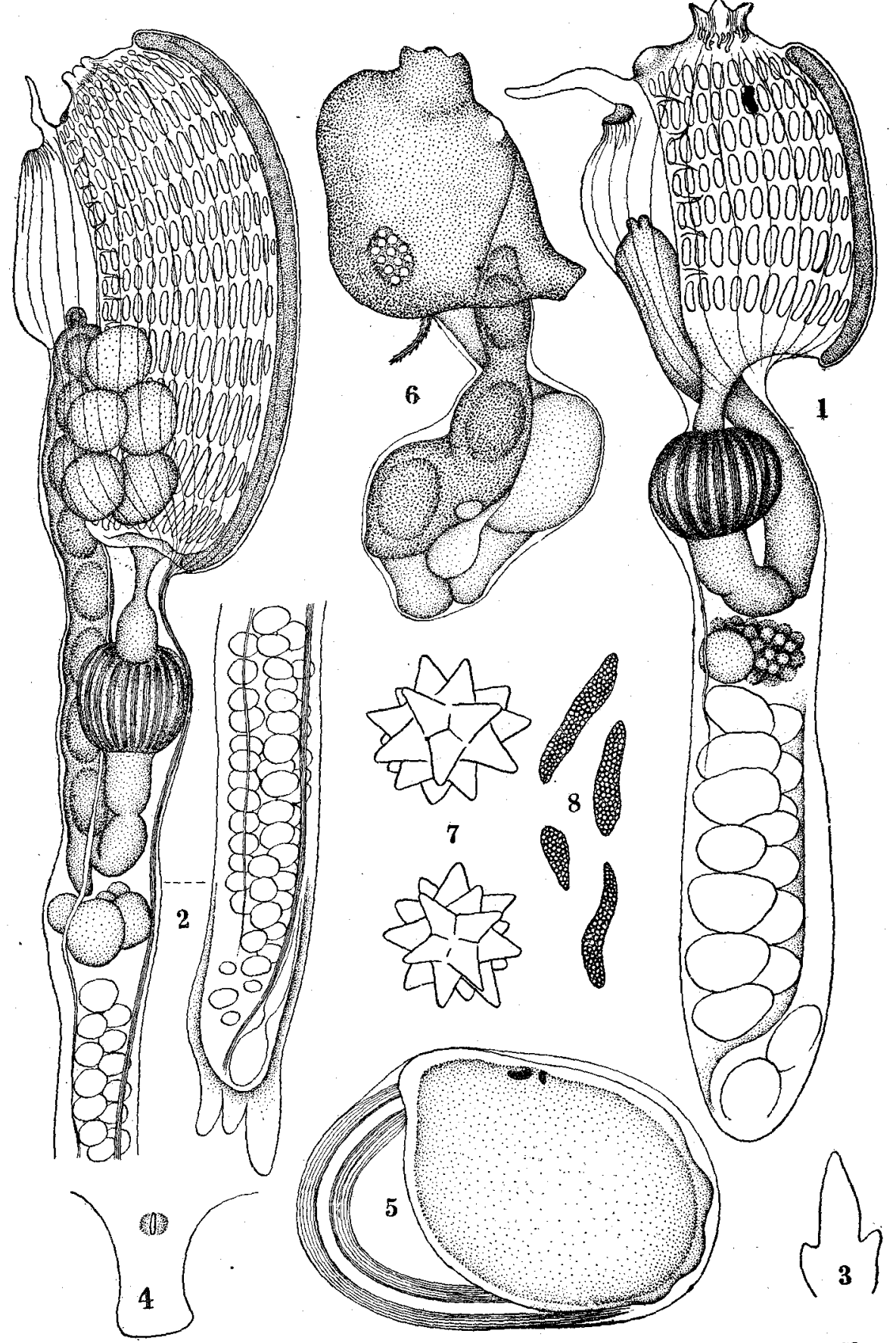

T. TOKIOKa: Contributions to Japanese Ascidian Fauna, $\mathrm{X}$. 


\section{EXPLANATION OF PLATE VI}

Fig. 9. Didemnum sp., zooid from right side, $\times 75$.

Fig. 10. Ciona intestinalis (L.), two supporting papillae of inner longitudinal vessels, $\times 75$.

Fig. 11. Ascidia alpha ToKIOKA, left side of mantle body, $28 \mathrm{~mm}$ long individual.

Figs. 12-15. Ascidia gamma n. sp.

12-21 $\mathrm{mm}$ long individual, right side.

13-Right side of mantle body.

14-Left side of mantle body.

15-Ciliated groove, enlarged.

Fig. 16. Ascidia zara OKA, ciliated groove, enlarged.

Fig. 17. Ascidia sydneiensis divisa (SlUTTER), $\times 2.7$ 
Publ. Seto Mar. Biol. Lab., IV, 1 (1954)

Plate VI

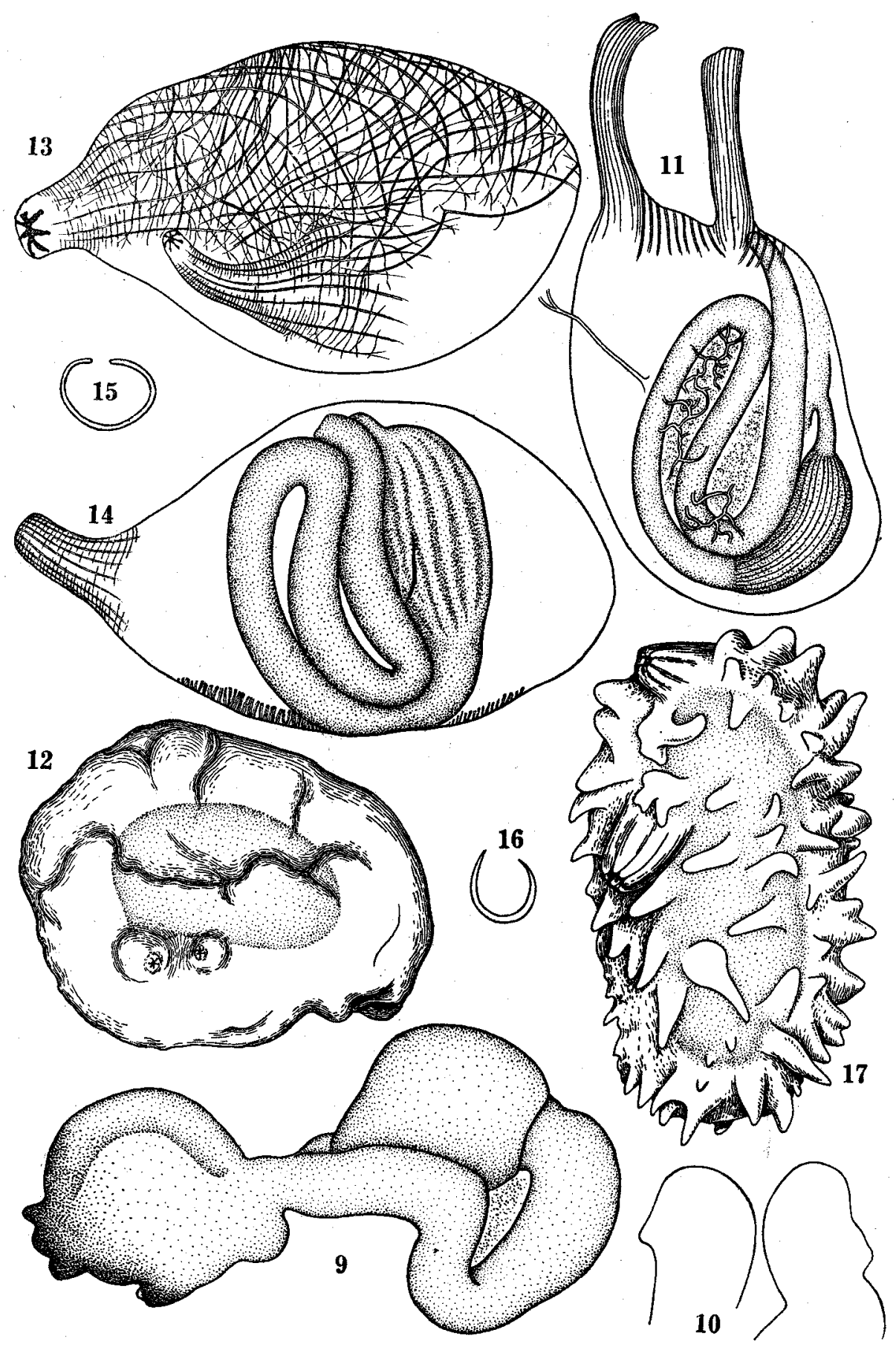

T. Tokioka: Contributions to Japanese Ascidian Fauna, $\mathrm{X}$. 


\section{EXPLANATION OF PLATE VII}

Fig. 18. Cnemidocarpa fertilis f. minor, nov. $10 \mathrm{~mm}$ long individual. Figs. 19-20. Styela partita (STIMrson).

19-15 mm long oval individual.

20-7 $\mathrm{mm}$ long individual.

Fig. 21. Styela plicata (Lesueur), $15 \mathrm{~mm}$ long individual.

Figs. 22-25. Pyura michaelseni (OKA).

$22-10 \mathrm{~mm}$ long individual.

$23-7 \mathrm{~mm}$ long individual.

24-Section of empty test containing respectively $25 \mathrm{~mm}$ and $36 \mathrm{~mm}$ long mantle bodies which are attached each other side by side, with a thin test wall between them.

25-Ciliated groove of a $5 \mathrm{~mm}$ long individual, enlarged.

Fig. 26. Pyura mirabilis (v. Drasche), spinules from the distal part of stomodaeum, $\times 1200$. 
Publ. Seto Mar. Biol. Lab., IV, 1 (1954)

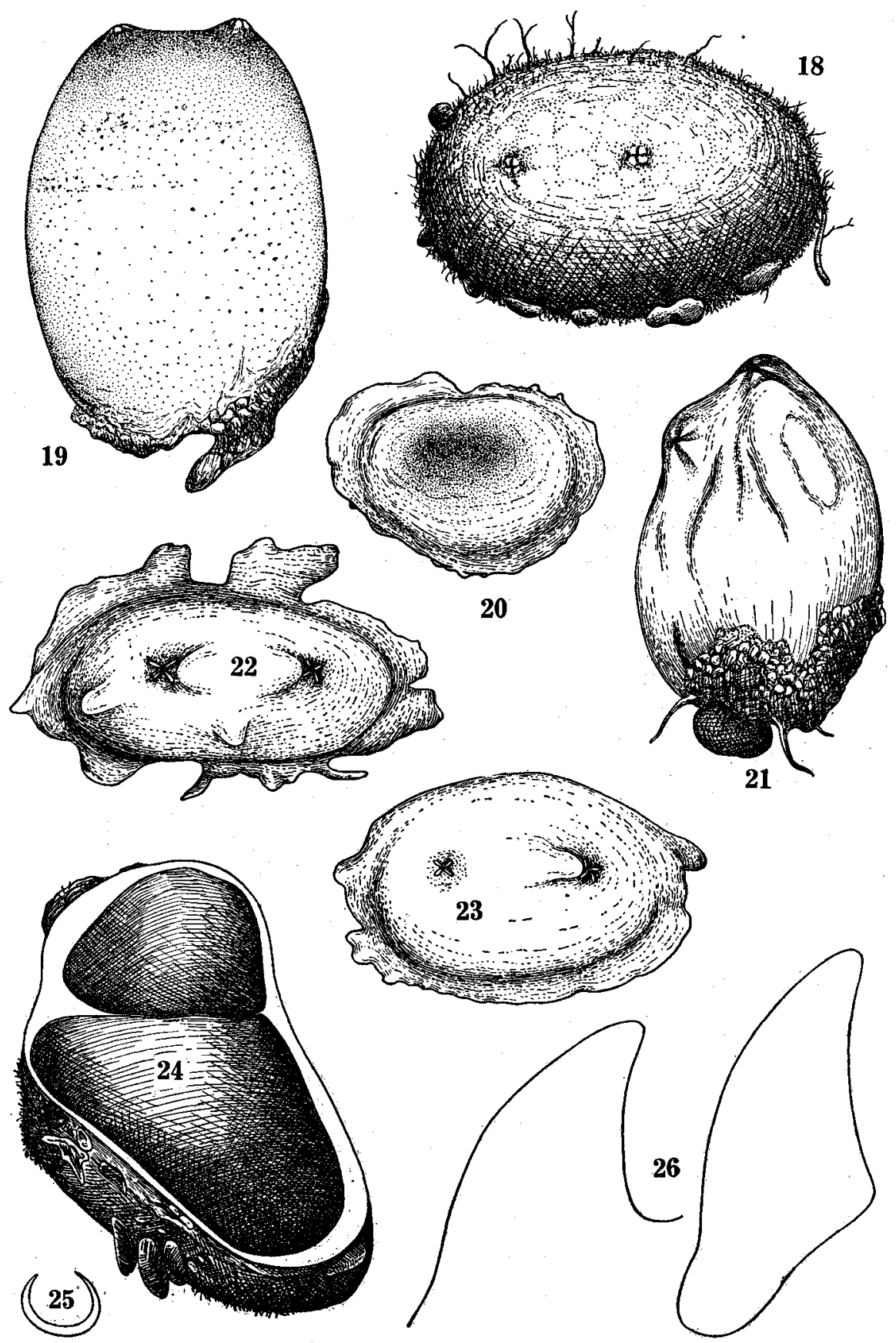

T. Tokioka: Contributions to Japanese Ascidian Fauna, X. 


\section{EXPLANATION OF PLATE VIII}

\section{Pyura mirabilis (V. DRASche).}

Fig. 27. $40 \mathrm{~mm}$ long individual, right side.

Fig. 28. Dorsal side of mantle body.

Fig. 29. Ventral side of mantle body.

Fig. 30. Ventral half of mantle body, from inside.

Fig. 31. 2 testicular follicles, magnified.

Fig. 32, 33. Ciliated grooves, enlarged. 
Publ. Seto Mar. Biol. Lab., IV, 1 (1954)

Plate VIII
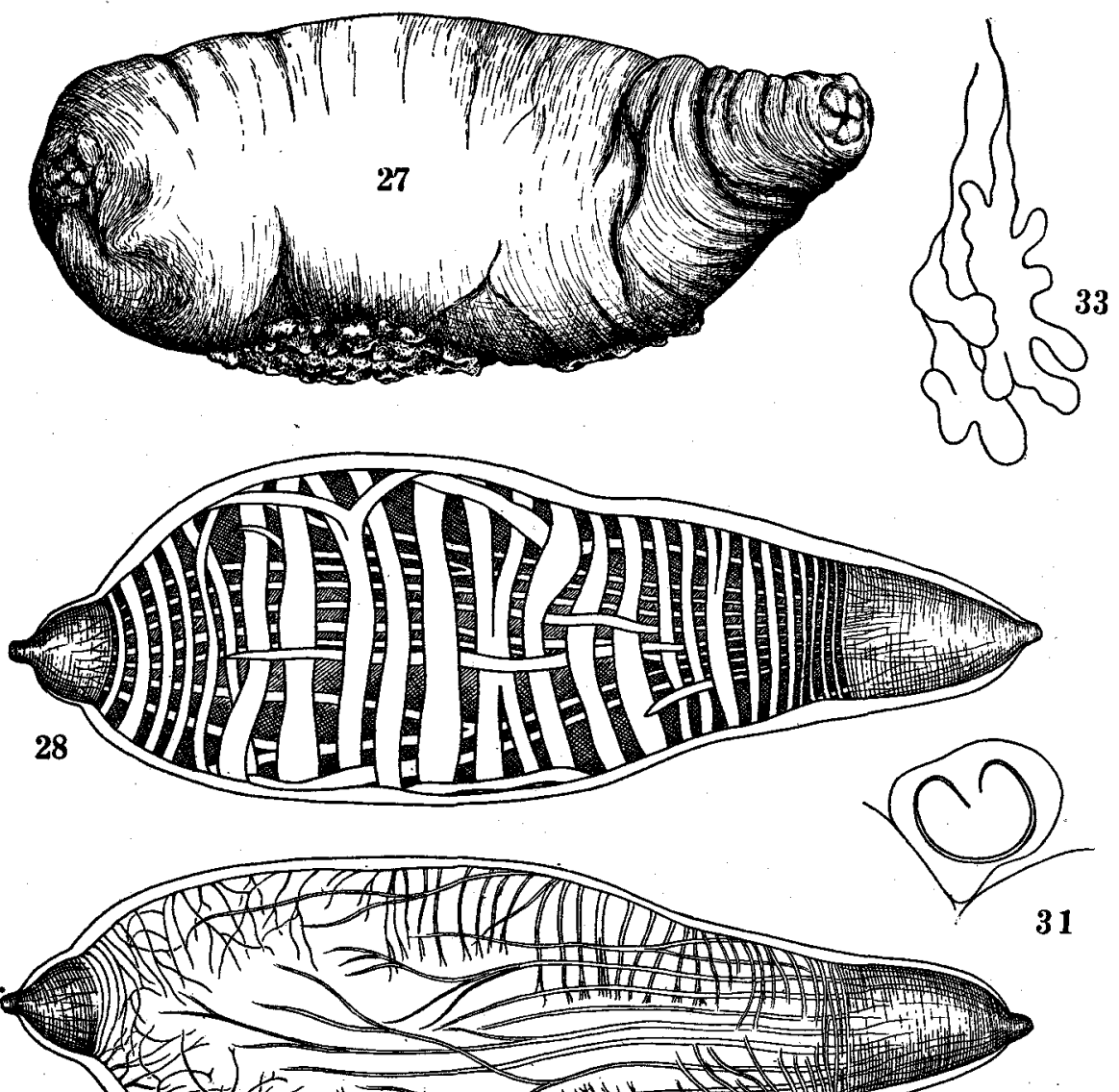

29

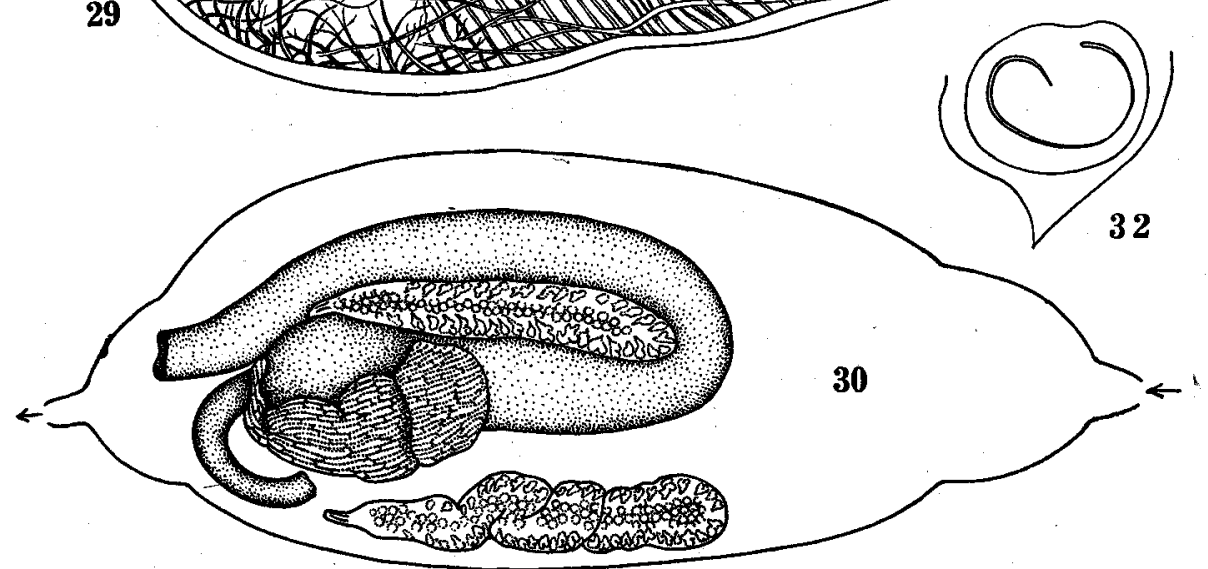

T. Tokioka: Contributions to Japanese Ascidian Fauna, X. 